\title{
Conflict between Confession and the Testimony When Proving Murder
}

\author{
Vajihe Sadat Pournajafi Abargouei ${ }^{1} \&$ Hassan Ghasemi Moghadam Anne Smith ${ }^{2}$ \\ ${ }^{1}$ MSc student in Jurisprudence and Principles of Law at the University of Yazd, Iran \\ ${ }^{2}$ Yazd University, Iran \\ Correspondence: Vajihe Sadat Pournajafi Abargouei, MSc student in Jurisprudence and Principles of Law at the \\ University of Yazd, Iran.
}

Received: June 6, 2016 Accepted: July 18, 2016 Online Published: July 31, 2016

doi:10.5539/jpl.v9n6p165 URL: http://dx.doi.org/10.5539/jpl.v9n6p165

\begin{abstract}
An important aspect is fundamental in criminal law, and jurisprudence arguments would be a judicial conflict in proving the crime. During the procedure of a murder case, it is possible the conflicts arise between the evidence of confession and religious testimony as a proof to prove the murder crime to specify the murderer; such that any of the argument suggests the particular person's culpability. Because of the various case, determining the probative value of each of them would have a significant impact on such conflict to resolve, regarding jurisprudence and legal. Therefore, the legislator in Article 213 of the Penal Code of Islam, adopted in 2013, has made it clear the probative value of any argues, prioritizing any evidence of confession than that of religious statement while conflicting with each other. If the legislator takes precedence of the evidence of faith over the religious testimony provided that assessing both things of evidence by the adjudicating authority and $\mathrm{s} / \mathrm{he}$ does waive to apply the phrase to the text of Article, the discovery of the truth and identifying the actual perpetrator with justice-based purpose will be more compatible.
\end{abstract}

Keywords: confession, testimony, conflict, murder, arguments

\section{Introduction}

To prove the criminal acts to commit and to attribute it to the accused, it should have provided the evidence and discussed during the criminal process. The argument of a proof of the IPC has adopted from the Shi'a juridical sources and become the basis of delinquency to prove. So in criminal law and the procedural process in Iran, the lawmaker when expressing the argument of proven criminal offenses stated in Article 160 of the Islam Penal Code provides: "Argument of crimes to prove are a confession, testimony, and swear in cases of legal prescript regulations and knowledge of the judge". It is possible in proceedings in a criminal trial when collecting and presenting the evidence, two on- conspecific things of evidence including the confession and the religious testimony would conflict with each other in proving guilty of murder. In the event of such conflict, uncovering the truth and punishing a real criminal will be affected and justice may be adversely affected. In the present study, based on the justice-based objective in exercising the punishment, the sentence for an issue of conflict between the confessions and religious testimony in two modes. Based on there being a claim of the avenger of blood for one of two accused people and lack of such claim stated by them, each of the modes envisaged in this area will be discussed in this context, separately.

\section{Explanation of Concepts}

In explaining the concept of confession in Article 164 of Islam Penal Code stated that: "Confession includes a person to announce the crime by her/himself." The lawmaker in the Islamic Republic of Iran in Article 160 of Islam Penal Code to comply with of the Jurisprudence has considered the confession to be as one of criminal argument to prove the conviction. Accordingly, including the argument can be appealed to prove the crime committed by the accused would be the same evidence (Ashori, 2008, 100/2). The testimony is also another concept that is meant to announce what has been seen (Ibn Manzur, 1993, 240/3). On Article 174 of Islam Penal Code, the testimony means that: "it is the personal news other than the parties about the occurrence or non-occurrence of the crime by the accused or any other issue to the judicial authorities."

The testimony invoked by the courts, which have to meet certain requirements (Akhondi, 2013, 240-239/7). The 
legislator in Article 177 of Islam Penal Code provides that: "religious witness when giving a testimony must meet the following requirements: (a) maturity, (b) wisdom, (c) faith, (d) the purity of generator, (e) equity, (f) lack of interest in the subject, (g) absence of hostility with the parties or one of them, (h) not being as begging person and (i) not being a stray." The number of witnesses is different, to prove the issue of the religious or judicial dictum, depending on the type of crime. Therefore, to prove the murder crime, followed by the Jurisprudence, two male witnesses who would be righteous suffice (Shahid Aval, 1989, 270). The conflict also means opposed thing appropriate with two or more items of evidence with each other (A group of researchers, $005,516 / 2$ ). In juridical dictionaries, also the conflict means "confrontation" (Abu Habib, 1988, 247) and "Refusal" (Rahman, without date, 1/466). The conflict would mean literally as a "confluence" (Jaafari Langroodi, $2008,159)$. The conflict between the principles of jurisprudence was divided into two types fundamental conflict and settled conflict based on that the opposed is considered primarily and apparently or actually. In principles of jurisprudence, the rules would be provided for resolution of each type of principle conflict, so that the fundamental conflict, if possible, will be taken into action according to the rule of plural (Sobhani, 2008, 221). In fact, according to this rule, if the opposed mode between arguments is not settling based on the standard, one of evidence should carry on the other (Bahrani, 2005, 2/431) in such a way that both of the conflicts would be exerted. It is known better the collection than scrapping one out of two. The collection is twofold: the acceptable and non-acceptable collections (Behbahani, 1994, 235). The intended group of fundamentalist is acceptable one; as approved by intellect, religion, and customs. Most of the fundamentalist also believed the molt, in the settled conflict (Makarem Shirazi, 2005, 3/469). This principle means the two conflict things of evidence are becoming invalid (Muzaffar, 2009, 3/227).

\section{Conflicts between the confession and religious testimony}

If witnesses testify against a person who committed murder, at the same time, another person would confess to committing the same crime (Allameh Hilli, 1999, 474/5). This issue would consider both cases, based on there being a claim for the avenger of blood that one of the two would be the original accused and the absence of such a claim.

\subsection{Conflict between Two Evidence Things, Assuming no Claim by the Avenger of Blood against an Accused}

If the avenger of the blood did not overturn one of them to commit, two situations were considered based on the possibility of jointly issued murdering and overall knowledge of not cooperating in the murder.

\subsubsection{The Possibility of Joint Murder Committed}

If the confessor wouldn't introduce the person who is witnessed against him/her to be innocent, in a juridical way, their participation in the murder is legally required to testify and confess such way (Ibn Zouhre Halabi, 1996, 407). If proved murder jointly, the principle requires it to happen collaboratively because the testimony which expressed either implied an obligation to deny anyone else's cooperation in the murder or not this situation. Under this explanation, if the testimony indicates not to deny anyone else's cooperation, the issue is clear. However, if this is implying obligation to deny anyone else's participation in the murder, then this means the murderer was only a person who is witnessed against him/her and in this time it is not permissible to retaliate both (Khoi, 2001, 121-120). But under little deeming, it could be said the obligation of the mentioned cause to implied will be removed due to anyone else's confession to exist because this confession would pose the probability of another to participate in the murder. Consequently, it will be allowed both to engage in the retaliation (Khouei, 2001, 120-121). Thus on the confession, the necessary implication to deny anyone else's participation is voided, since tailored the confession rule, the circle of argumentum of confession is correct just about the self of the confessor, and it is not an argument for anyone else. Therefore, the total of testimony and confession would be appropriate with the murder to prove collaboratively. Therefore, the demand for involvement in the murder would be permission for one of them or both of them together (Fazel Lankarani, 2000, 210).

Based on a judicial opinion, the avenger of blood wants to punish both by retaliation, it must be paid the half of blood-money to the heirs of the person who witnessed against him/her, but another half not necessary to pay to the heirs of the confessor. The reason for this is that the appropriateness for his/her confession would be not entitled to the blood-money if retaliation. There is another view based on that if both are wanted to receive the retaliation, the avengers of blood is committed to paying full to their heirs who they divide the blood-money among themselves (Fazel Lankarani, 2000, 211). Legally, in the case of the proof of participation in a deliberate crime, the legislator in Article 373 of Islam Penal Code provides: "In cases of participating in the crime intentionally, regarding each case, the victim or the avenger of blood can be one of the partners in the crime of intentional murder. others should immediately pay their share of the blood-money to whom $\mathrm{s} / \mathrm{he}$ will be 
sentenced by the retaliation or that all the partners or more than one of them are sentenced to retaliation, provided that the surplus of blood-money on the crime emerged was paid to whom they will be sentenced before exerting the retaliation. If they under the retaliation are not all those who are partners, each partner that is not sentenced by the retaliation must pay her/his share of the blood-money given the number of partners." In the text of the mentioned article, the legislator makes no mention the proof of crime proved and each involvement of the partner in the murder proved in any way that whether a confession or the testimony will be performed by the same verdict. Proof of this is frequently using the word the revenge respondents in these articles' context.

\subsubsection{Individually Possibility Murder}

If the confessor would introduce the person who witnessed against him/her to be innocent and know her/him to exculpate from committing the murder; in fact, there would be the overall knowledge based on which the involvement in the murderer is ruled out and one person committed the crime. In this case, there are three theories about the requirements of the low. First, the requirement of the rule would be the molt or appropriateness of the rule is a selection, or that of a rule would take the confession and ignore the religious testimony. Apparently the appropriateness of rule is the novel aspect, in this case. Because the scholars would believe to obtain the confessions and preference of the conflict evidence and perhaps the origin of this idea is that the confession is meant as the witness against the self and the testimony, against non-self. So it is evident the confession compared with the witness is stronger regarding implication (Fazel Lankarani, 2000, 211), there are different legal perspectives, in regarding the decision to admit the confession along with the testimony in the mentioned case.

A) A theory the most jurists are unanimous on is matched with the correct narration that Zurarah quoted the tradition from Imam Muhammad Baqir (AS): "The corpse was brought to a judge, a group testified indicating a person is deliberately murderer. The judge submitted the murderer to the avenger of blood who punished him/her. At this moment, before the retaliation by the avenger of blood, another man had come to the judge and confessed to committing the murder as a deliberate action, so the person who is witnessed against him/her being innocent and then he demanded to release him and to become punished. Imam Baqir (AS) said: If the avenger of blood wanted to kill someone who had confessed against himself- then killed him and the avenger of blood didn't have the right to demand from others- then heirs of confessor did not also entitle to demand from the heirs of the person who is witnessed against him/her. If the avenger of blood wanted him dead, they could not claim the blood-money against the person who had confessed to the murder. Then the confessor paid half of the blood-money to the avenger of blood. If the avenger of blood asked both to kill, said: his majesty said (AS): they entitled to do so; they should pay the family of who has witnessed against him/her but not the confessor's and then kill both. I said how was when they wanted to get the blood-money from both, said: Imam (AS) said: the blood-money divided in 50-50 because one confessed and another was testified. I said how was, when the person who has witnessed against him/her was killed, half of blood-money was determined for the confessor for the family of who is witnessed against him/her, but for the confessor's family was not determined for the witnesses' family like the confessor would? Imam said: someone was testified would be not the same as who has confessed. Someone who was testified did not confess and not absolve others, but another confessed to the murder and absolved another one. As a result, the confessor committed and adhered to the effects of his confession while the person who is witnessed against him/her did not know himself to be obliged" (Hurr Ameli, 1981, 29 / 145-144). According to the well-known narration, the scholars believe that in the event of such conflict, the avenger of blood could retaliate somebody who had testified against him, and the confessor should pay half of blood-money to the family of the person who is witnessed against him/her who was retaliated. As well, the family, of who is murdered, could retaliate the confessor, but not blood-money should be paid to his heirs, as, the heirs of the victim's had the right to retaliate both. However, in this case, it was necessary that they paid the half of blood-money to the heirs of the person who is witnessed against him/her but not for the confessor's heirs. Also, if the avenger of blood were satisfied to get blood-money so that, so they could get half paid by each one equally (Majlesi, 2010-2011; Tousi, 1400,743)

B: Second, the view is that based on the rule, the case was sentenced selectively. The reason for this view is no confession by the confessor to participate in the murdering and witnesses not testifying to this way. Therefore, under this arguing, the avenger of blood is authorized to retaliate only one of two people a reason that is brought against him (Fazel Lankarani, 2000, 211). Accordingly, the cabbala is bugged by somethings. The first is that the avenger of blood is not authorized by the cabbala, this is meant that it is unknown both participate in the murder. So the retaliation for both encountered with some bugs (Mohaghegh Helli, 206, 2011) answered this drawback that one of them is killed due to the evidence was submitted to him and another one, due to his confession individually, makes his life killed permissibly (Mohaghegh Helli, 3, 2007/ 376). The second drawback is that, 
why in the case of killed both, they are not obliged to pay surplus of blood-money; because by killing both of them, it has been indeed proved that both are the murderer. While based on the cabbala, the avenger of blood of the slain is only obligated to pay in surplus of the blood-money of the murdering to the family of the person who is witnessed against him/her (Fadel Miqdad, 1983, 4 / 436). This is answered such that two people are killed for if participating in a the same murder, that if both are involved in the murder, the surplus of blood-money which is considered as the total blood-money was fully paid to them, but here is the one being killer has been proven nonspecifically and the confessor overthrew his right to receive the surplus of blood-money (Mohaghegh Helli, 1991, 3 / 376-375); because by his confession, he absolves others to pay blood-money (Abul-Salah Halabi, 1982, 387).

There has been criticized the permissibility of taking blood money from both of them, due to the both reasons corrected that they were participated individually (Fadel Miqdad, 1983, 4/436), answered that this is true both was not accepted to be murderer together but the killer being one of them has been proven nonspecifically, this is known as the permission to take the blood-money from both (Abi, 1994, 2 / 616). According to the jurisprudence based on selection after the statement of the drawbacks, the only problem is known to be the Cabbala to be well-known, because this was written in the reasoning books and practiced. So this is the reputed text and cannot be easily dismissed (Allameh Hilli, 1999, 5/474), the scholars who believed that that reputation of the cabbala was reached to the consensus, have been implicitly accepted the drawbacks were talked. But they believed that this oppose due to the authenticity of the document of the cabbala and being supported by religious practice was difficult. So many general rules were allocated by the Cabbalas like this (Tabatabai, 1997, 16 / 271).

C: There is also a third view, based on which there is neither an opportunity for well-known manner and nor to the selection. But if the cabbala implies an popular comment, its implication would be an absolute deal, and while that is what is obtained by the verses and Cabbalas is the principle of not allowed believers to kill unjustly. Including the verse where He says: "Nor should the believers kill another believer except by mistake" (Surah Nissa, verse 92). Also among the cabbala in this regard can be referred the sayings noted by Muhammad Ibn Sinan that Imam Reza (AS) in response to the issue, wrote "God Almighty has forbidden the murder- because if Permissibility, it leads to corruption and the destruction of people and in this regard the measure was too corrupted" (Hurr Ameli, 2010, 29/14), therefore theses verses and Cabbalas cannot desist from predication of them based on caution in people's blood, nor the application of cabbala taken action (Khoi 2001.122).

Based on juridical such viewpoints in which determined must be dispossessed the cabbala to express and its interpretation of shared probability in murdering. It seems the jurists to have taken into account such conflict among fundamental conflicts; because in the first place, it is manifesting in conflicting but with little deliberation, it will be solved by the acceptable collections. Expressing the cabbala to be allocated to the knowledge of the lack of sharing, in fact, has been collocated between verses and Cabbalas indicating not allowed the murder of a believer unless lawful and this cabbala, the consensus will be done so that it is given up the cabbala to desist from the prediction of the cabbala. It restricted to be aware of the murder carried out individually, the bounden is interpreted absolutely, and it would not conflict with authenticity and reputation of the cabbala. The second approach based on the selection, it should be noted that the selection to talk needs for the reason, while in the case of conflict between two reasons. If it is not possible to take into account of two reasons or preferred one of them over another, the principle is based on the mutual nullity but not the selection. So the appearance of wise in such positions, it is a principle to obtaining the confession and ignoring the testimony. The requirement of obtaining a confession would be retaliation of the confessor or if the consent of the avenger of blood, taking blood money from him (Khoi, 2001, 123).

It has been said that all the scholars have learned by the cabbala would be an inclusion on the state of knowledge to the lack of collaboration to murder (Fazel Lankarani, 2000, 214) so that some have said what is closer to the caution is enough to kill just one of them (Tabatabai, 1997, 16 / 272).

According to the confession is the testimony would indicate the self, but the evidence testifies on anyone else because the confessor is more aware of himself than others. It can be made to consider higher-value for confession in such a position and therefore regarding the implication, the confession is more obvious than the testimony; therefore, regarding preference more obvious thing towards the appearance. The reason of confession is known to prefer than the reason of testimony that it results practically, if obtaining confident talks of the confessor while confession, in the confessor to retaliate or if the avenger of blood were consent, to pay blood-money. However, the confession is preferred to the testimony and also is preferred to other arguments except judge's knowledge (Rahmdel, 2015, 172). Perhaps, based on such causality that the legislator in Article 213 of Islam Penal Code in the case of conflict between the confession and another evidence; bluntly the admission is preferred to religious testimony, swearing individually and collectively swearing. Since the 
testimony is significant more in such a way that usually one or some people who were present at spectated the event of crime accidently, because of distance or closeness of the witness to the crime scene, darkness or brightness of location, forgetfulness or laziness of moral foundations can all affect the accuracy of testimony (khaleghi, 2015, 2/167-168).

Because of the possibility of confession due to the pity, threats, bribery, torture and so on, it should not be exaggerated on how important the confession is and due to this, it cannot be accepted without any investigations (Khaleghi, 2015, 2 / 165). So it is necessary the judge does research around this confession and invokes it just if there is no doubt as confident as s/he can obtain, that the confession is true, or the confessed thing is a reality which happens (Rahmdel, 2015, 172). So it can be said that the accused's quirk when confessing results in the doubt on the authenticity and integrity and therefore it cannot invoke such a confession.

\subsection{Conflict between Two Reasons in Assuming the Claim of Murder from the Avenger of Blood Versus the Accused}

If the confessor, after confessing the murder, confirms the person who is witnessed against him/her to be innocent and absolve her/him to commit the crime, despite the murder claimed by the avenger of blood against one of the two accused. The reason given compared with another one would lose its authority regarding jurisprudence (Mohaghegh Helli, 2005, 3 / 377) which means that if the person who is witnessed against him/her was claimed to do murder, the confession of who s/he confesses and if against the confessor, the evidence is invalidated. So if the avenger of blood claimed against the confessor, it is no longer referred to and retaliated or taken blood-money from who is seen against him/her. Also, if the avenger of blood claimed the person who is witnessed against him/her to be a murderer, there was not an opportunity for retaliating or getting the blood-money from the confessor (Fazel Lankarani, 2000, 216).

In legal terms, it can also be said that Article 213 of Islam Penal Code is related to the cases in which the avenger of blood would not claim against the murder individually. Otherwise, if doing so, regarding criminal liability, this does no longer mean retaliation or payment of blood-money, in such a case, the is not known to prefer confession than religious testimony. In fact, such cases will be subject to Article 362 of Code of Criminal Procedure where the legislator determined: "The Court also deal with the argue inserted in the indictment or invoked by the parties, any investigation or action that is necessary to uncover the truth would be done to indicating to the necessity." According to this article, it can be said if the avenger of blood claimed the person who is witnessed against him/her to commit the crime individually, it is necessary to investigate and take the essential measures to uncover the truth.

\section{Conclusion}

Investigating the Articles of Code and juridical issues related to the argument to prove criminal cases and the conflicts between them. There is clear that in the case of observed the conflict between the reason of confession and religious testimony in proving the murder crime, there is a juridical and legal order based on proving value of each. Although the lawmaker of the Islamic Republic of Iran considered the reason of confession to be preferred than the testimony when both conflicting; the judge must before holding to the confession as documented issuing of the verdict, ensure the veracity of the confession; because due to the conflict argument, the veracity of the confession will be somewhat doubted. So to uncover the truth, the judge dealing with the case must evaluate conflicting argument by adopting the argument provided with the evidence and statistics existing and therefore, take the reason that is by reality to identify the actual perpetrator. Finally, under the studies carried out in line with the reform of criminal laws relating to conflict of the criminal argument to prove the crime, to implement Islamic justice in society better than ever, it is suggested:

In an amendment under Article 213 of Islam Penal Code, the confession has a priority than the religious testimony in the case of conflict between them, provided that adjudicated both by the authority to assess and somehow desisted from the prediction of the phrase in the text.

\section{References}

Abdul Rahman, M. (n.d.). Glossary of words and jurisprudence (Vol. 1, 1st ed.). unwarranted.

Abu, H. (2011). Dictionary idiosyncratic language and idiomatically (2nd ed.). Damascus, Dar-al-Feker.

Allameh H. H. (1999). Liberalization of legal provisions on the doctrine of Imami (i - cabbala) (Vol. 5, 1st ed.). Qom, Imam Sadeq Institute.

Ashouri, M. (2008). Code of Criminal Procedure (Vol. 2, 9th ed.). Tehran, publisher of Saamt.

Bahrani, M. (2005). Explanation of assets from the second episode (Vol. 2, 3rd ed.). Tehran, Moalef. 
Behbahani, M. B. (1994). Benefits of Al-haerieh (1st ed.). Qom, though community of Islam.

Faqany, A. (1999). The talk for identifying Intentions and rhythms and contracts formats (1st ed.). Qom, Imam Al-Asr (AS) school.

Fazel, A. (1996). Symbols revealed in a brief explanation of the beneficial (Vol. II, 3rd ed.). Qom, Islamic publishing office of the Qom Seminary Teachers Society.

Fazel, L. (2000). A detailed written description in explaining tahrir-al-Vassileh-Al-Ghesas (1st ed.). Qom, the religious center of the Imams (PBUH).

Fazel. Miqdad, Miqdad ibn Abdullah. (1983). Wonderful revision of laws Summary (Vol. IV). Qom, Ayatollah Marashi Najafi Library.

Holy Quran.

Hurr, A.(1988). Means of scholars (Vol. 2, 29th ed.). Qom, al-Beyt Institute for Imams.

Ibn, M, Mohammad. (1993). Arab language (Vol. III, 3rd ed.). Beirut, thought location to print and distribute Issuance location.

Ibn, Z., \& Halabi, H. (1996). Rich tendency to scientific assets and branches (1st ed.). Qom, Imam Sadeq Institute.

Jaafari, L., \& Mohammad, J. (2009). The terminology of laws (21st ed.). Tehran, library of treasure of knowledge.

Khaleghi, A. (2015). The Code of Criminal Procedure (Vol. II, 27th ed.). Tehran, Legal Studies and Research Institute of Knowledge.

Khoi, S. A. (2001). Foundations of Continued curriculum, Encyclopedia of 41 and 42 (Vol. 42, 1st ed.). Qom, Institute for rehabilitation of Imam Khoei'd works (RA).

Mahmoud, A. (2013). The identity of Criminal Procedure (Vol. 7, 1st ed.). Tehran, printing of publications related to endowments institute.

Majlesi, M. (1988). Whip punishment, retaliation and blood-money (1st ed.). Tehran, Institute of Islamic works Publication.

Makarem, N. (2009). The lights of principle (Vol. III, 2nd ed.). Qom, Imam Ali bin Abi Talib (as) school.

Mohaghegh H. (1991). Final points (Vol. III, 1st ed.). Qom, Islamic publishing office of the Qom Seminary Teachers Society.

Mohaghegh, D. (1985). The principles of jurisprudence (Vol. III, 12th ed.). Tehran, Press Center of Islamic Sciences.

Mohaghegh, H. (1989). The laws of Islam in the halal and haram issues (2nd ed.). Qom, the Institute of Ismaili.

Mozafar, M. (2009). The principles of jurisprudence (Vol. 3, 5th ed.). Qom, Islamic publishing the Society of Teachers of Qom.

Rahmdel, M. (2015). The Code of Criminal Procedure (Vol. III, 2nd ed.). Tehran, publisher of Dad Gostar.

Shahid, A. (1989). Shines of Damascene in the jurisprudence of the Imami (1st ed.). Beirut, Dar Altras - Aldar Alaslamyh.

Soubhani, J. (2008). SUMMARY in the jurisprudence principles (14th ed.). Qom, Imam Sadeq Institute.

Tabatabaei, S. A. (1997). Difficulties of issues in achieving Jurisprudence indications ( $i$ - cabbala) (Vol. XVI, 1st ed.). Qom, al-Bayt Institute for Imams.

Tousi, M. (1979). The ultimate of Jurisprudence and fatwas (2nd ed.). Beirut, Dar al-Arabi books.

\section{Copyrights}

Copyright for this article is retained by the author(s), with first publication rights granted to the journal.

This is an open-access article distributed under the terms and conditions of the Creative Commons Attribution license (http://creativecommons.org/licenses/by/4.0/). 